\title{
Original
}

\section{A Morphological Study on the Palate of Children Native to Okinawa Island}

\author{
沖縄本島幼児の口蓋の形態学的研究
}

Hideo MIYAZAKI*, Toshiyuki SHIGEOKA*, Keiko GOTO*, Masaaki KITAMURA*, Tomio IHA* and Tadamichi TAKEHARA*

$\begin{array}{llllllll}\text { 宮 崎 秀 夫* } & \text { 重 } \text { 岡 } \text { 利 幸* } & \text { 五島 } & \text { 恵 子* } \\ \text { 北 村 正 明* } & \text { 伊 波 富 夫* } & \text { 竹 原 直 道* }\end{array}$

Received August 25, 1986 ; accepted September 10, 1986

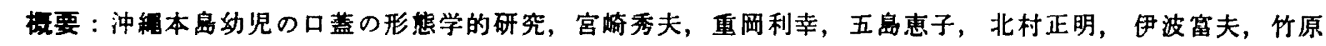
直道; この研究は，沖絸本岛住民の口蒀（乳列列）の諸形睤を明らかにする目的で行なった。調査対象は那 丽市内の保育園児（ $3 \sim 5$ 絾），男89名，女68名，計157名である。この研究の結果，沖䋲幼児の口蓋諸形質

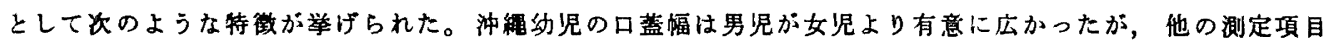
には有意な性差は認められなかった。沖網幼児は北九州幼児と比较して，口蓋高はやや低く，正中口蓋綎合 線長は短い，口䔲弓隆長，口蓋幅は口藍の前方では長（広）いが，後方では逆に短（狭）い傾向が伺われた。 この特兵は，上頻齿列弓形態が，北九州幼児の Paraboloid（放物線型）に対し Ellipsoid (棈円型) が多いこ とを意味している。また，先に教室で報告した沖綶成人の永久画列の特徴，齿列弓形热は Paraboloid が多 いなどとは異なる形犋を示すものと考えられた。

\section{Koy words: Palatal heights, Palatal arch lengths, Palatal breadths, Okinawa Island}

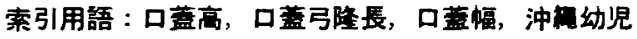

\section{Introduction}

Along with several other researchers $\left.{ }^{1-4}\right)$ who have been making physical anthropological studies of the oral cavity, our laboratory ${ }^{5-11}$ ) has made similar investigations in Japan and abroad, including studies showing that the morphology of the dental arch and palate has racial or regional features. However, with the exception of two studies on palatal morphology of children living in Kitakyushu, one by Maeda ${ }^{12)}$ and another by $\mathrm{Ando}^{18)}$ on mentally retarded children, few studies have been done on deciduous dentition. For this reason we investigated the palatal traits present with the deciduous stage of dentition in the native children of Okinawa Island.

* Department of Preventive Dentistry, Kyushu Dental College (Director: Prof. Tadamichi TAKEHARA)

*九州药科大学口腔街生学教室（主任：竹原直道教授）

特別揭载 


\section{Materials and Methods}

A total of 157 nursery school children between 3 and 5 years of age, 89 boys and 68 girls, living in Naha, Okinawa Prefecture, were investigated. The children were at Hellman's II A stage; that is, deciduous teeth occlusion was complete and the 1 st molar had not erupted. The teeth of these children was in good condition, free of decay, and no teeth were missing.

Measurements were taken of palatal height, the anterior-posterior palatal height index, length of sutura palatina mediana, palatal arch length, and palatal breadth. The measurements were taken from plaster casts according to the method of Ando ${ }^{13}$ ) (Fig. 1); when the measurements were indistinct the data were excluded.

The results are given as a mean and standard deviation for each item. Significant differences were measured by the t-test or by an approximation of the method of Cochran-Cox; variance was calculated using the F-test.

\section{Results}

Both the anterior and posterior palatal heights tended to be greater for girls than for boys, although the difference was not significant. Girls also tended to have a greater anterior-posterior palatal height index; this indicates that the difference between the anterior and posterior regions of the palate was less for girls than for boys. Although the length of the sutura palatina mediana tended to be longer in girls than in boys, no significant difference was found (Table 1).

In boys the palatal arch lengths, that is, between the deciduous canines, between the 1 st deciduous molars, and between the 2 nd deciduous molars, tended to be longer than in girls, although again the difference was not significant. Between boys and girls there was an average of $0.28 \mathrm{~mm}$ difference in the length between the deciduous canines, $0.74 \mathrm{~mm}$ between the $1 \mathrm{st}$ deciduous molars, and $1.20 \mathrm{~mm}$ between the 2 nd deciduous molars (Table 2).

The palatal breadth measurements, including measurements between deciduous canines, between 1 st deciduous molars, and between 2 nd deciduous molars, were significantly greater $(P<0.01,0.001)$ for boys than for girls. As with palatal arch lengths, these differences increased moving from the anterior to the posterior region of the palate (Table 3 ).

Table 1 Palatal heights, palatal height index and length of sutura palatina mediana

\begin{tabular}{lcccc}
\hline & Boys & Girls & $\mathrm{t}$ & $\mathrm{p}<$ \\
\hline Anterior palatal height $(\mathrm{mm})$ & $10.07 \pm 2.16(66)$ & $10.45 \pm 1.75(51)$ & 1.02 & $\mathrm{NS}$ \\
Posterior palatal height $(\mathrm{mm})$ & $12.20 \pm 1.39(38)$ & $12.30 \pm 1.51(31)$ & 0.29 & $\mathrm{NS}$ \\
Anterior-posterior palatal height index $(\%)$ & $80.15 \pm 0.96(34)$ & $83.34 \pm 6.70(30)$ & 0.58 & $\mathrm{NS}$ \\
Length of sutura palatina mediana $(\mathrm{mm})$ & $23.17 \pm 2.03(37)$ & $23.79 \pm 1.60(31)$ & 1.38 & $\mathrm{NS}$ \\
\hline
\end{tabular}

Table 2 Palatal arch lengths

\begin{tabular}{lcccc}
\hline & Boys & Girls & $\mathrm{t}$ & $\mathrm{p}<$ \\
\hline Between deciduous canines (mm) & $25.78 \pm 2.46(87)$ & $25.50 \pm 1.59(66)$ & 0.81 & $\mathrm{NS}$ \\
Between 1st deciduous molars (mm) & $32.39 \pm 2.06(65)$ & $31.93 \pm 2.07(49)$ & 1.18 & $\mathrm{NS}$ \\
Between 2nd deciduous molars (mm) & $36.93 \pm 2.61(36)$ & $35.73 \pm 2.18(27)$ & 1.93 & $\mathrm{~N} \mathrm{~S}$ \\
\hline
\end{tabular}


Table 3 Palatal arch breadths

\begin{tabular}{lcccl}
\hline & Boys & Girls & $\mathrm{t}$ & $\mathrm{p}<$ \\
\hline Between deciduous canines $(\mathrm{mm})$ & $24.81 \pm 1.73(89)$ & $23.93 \pm 1.56(68)$ & 3.29 & 0.01 \\
Between 1st deciduous molars $(\mathrm{mm})$ & $27.43 \pm 1.62(89)$ & $26.48 \pm 1.49(67)$ & 3.75 & 0.001 \\
Between 2nd deciduous molars $(\mathrm{mm})$ & $29.78 \pm 1.71(86)$ & $28.66 \pm 1.41(64)$ & 4.27 & 0.001 \\
\hline & & & $\overline{\mathrm{X}} \pm$ s.d. $(\mathrm{N})$
\end{tabular}

\section{Discussion}

Two researchers, Maeda ${ }^{12}$ and Ando ${ }^{13}$ ) previously reported on the palatal morphology of children with deciduous teeth living in Kitakyushu. Maeda ${ }^{12}$ reported on morphology of the children's palates noting sex and age differences and compared the findings with those from adults, and $\mathrm{Ando}^{13)}$ compared the oral traits of mentally retarded children with those for normal children particularly looking for differences between the two sexes.

It is well known that children with malalignment or malocclusion mainly caused by crowding in the dental arch have been increasing recently. This suggests decreased jaw development with the progress of time. Therefore, when comparing regional oral trait differences, it is better to adopt controls of the same age, so we will compare the results of the present study with the findings from the control group of normal Kitakyushu children as reported by Ando's) (Figs. 2-7).

It has been said that there are racial differences in palatal height and this provides important data for anthropological observation of jaw growth. Ninomiya ${ }^{14)}$ stated that heredity is a greater influence on posterior palatal height than it is on anterior palatal height, whereas
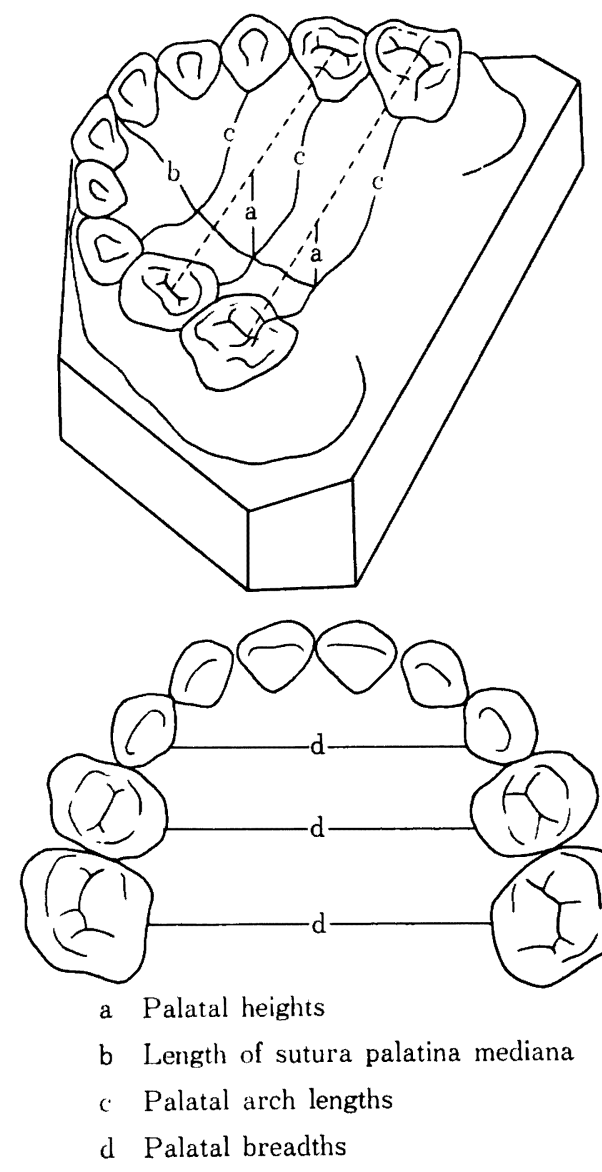

Fig. 1 Measurement points and sites of the palate

the environment is a greater influence on anterior palatal height. In respect to the child's sex and palatal height differences, Maeda ${ }^{i 2)}$ reported that there was no difference at 3 years of age, but that boys had greater posterior palatal height at 4 years of age and greater anterior and posterior palatal heights at 5 years of age than did girls of the same age. According to Ando ${ }^{13)}$, however, girls have greater anterior palatal height, but there are no differences between the two sexes in posterior palatal height. In the present study, both anterior and posterior palatal heights of girls tended to be greater than those of boys, but the difference was not significant; these results are more similar to those of Ando ${ }^{13)}$ than to those of Maeda ${ }^{12)}$. In this study, both anterior and posterior palatal heights in Okinawa children were gre- 


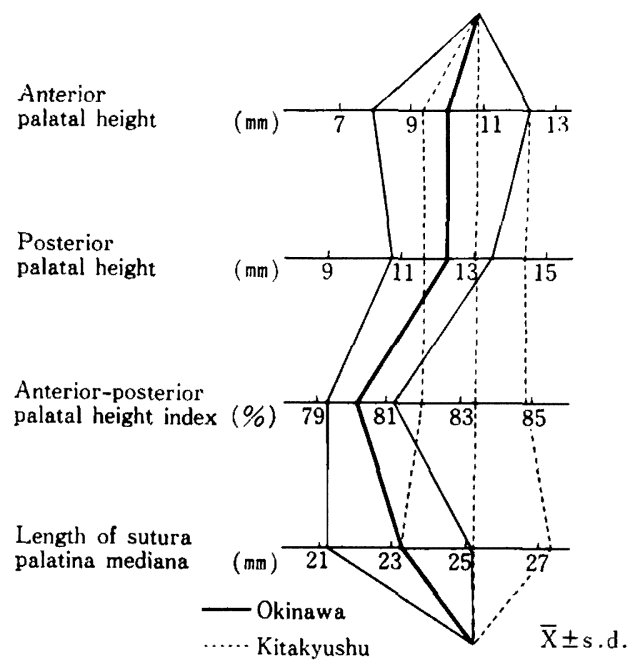

Fig. 2 Palatal heights, palatal height index and length of sutura palatina mediana (boys)

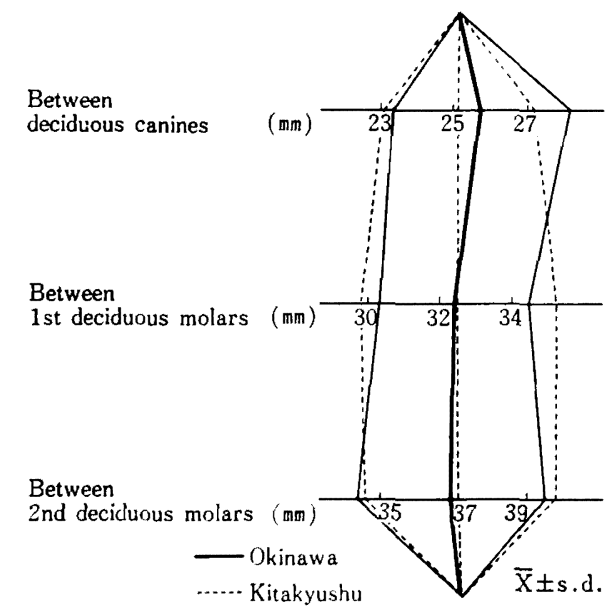

Fig. 4 Palatal arch lengths (boys)

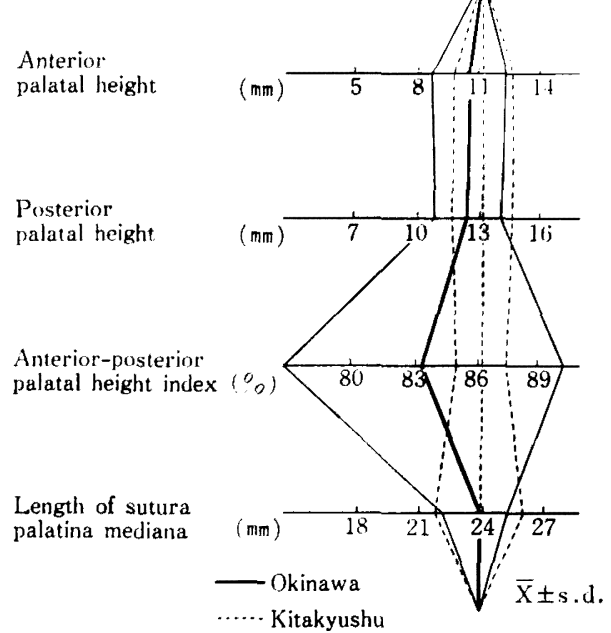

Fig. 3 Palatal heights, palatal height index and length of sutura palatina mediana (girls)

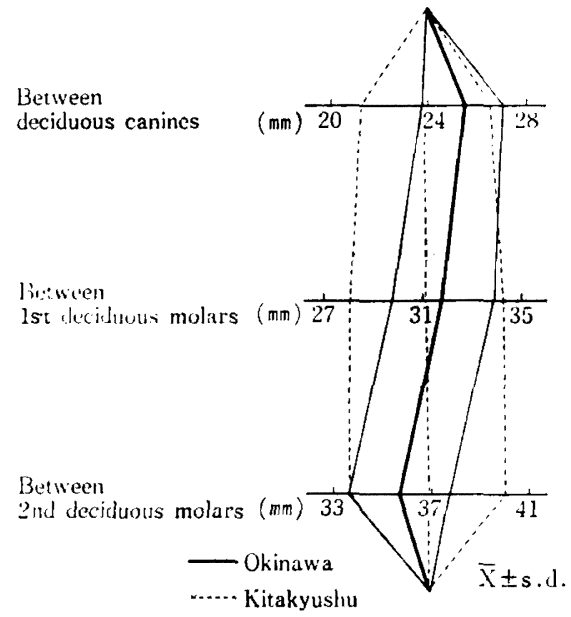

Fig. 5 Palatal arch lengths (girls)

ater than those found by Maeda ${ }^{12}$ in Kitakyushu children but were less than those found by $\mathrm{Ando}^{18)}$ in Kitakyushu children (Figs. 2, 3).

The anterior-posterior palatal height index of Okinawa children showed no significant difference, having the same tendency as found by Ando' ${ }^{13)}$ in Kitakyushu children. The index for Okinawa children was smaller for both boys and girls than the index was for Kitakyushu children. This indicates that there is a tendency for a greater difference in height between palatal anterior and posterior regions in Okinawa children than in Kitakyushu children (Figs. 2, 3).

Maeda ${ }^{12)}$ reported that boys had greater sutura palatina mediana length than did girls for the years between 3 and 5 . He noted the greatest length in the 3-year-olds, with the length gradually decreasing to the age of 5. Ando ${ }^{18)}$ also reported that the length of the sutura palatina mediana was greater in boys than 


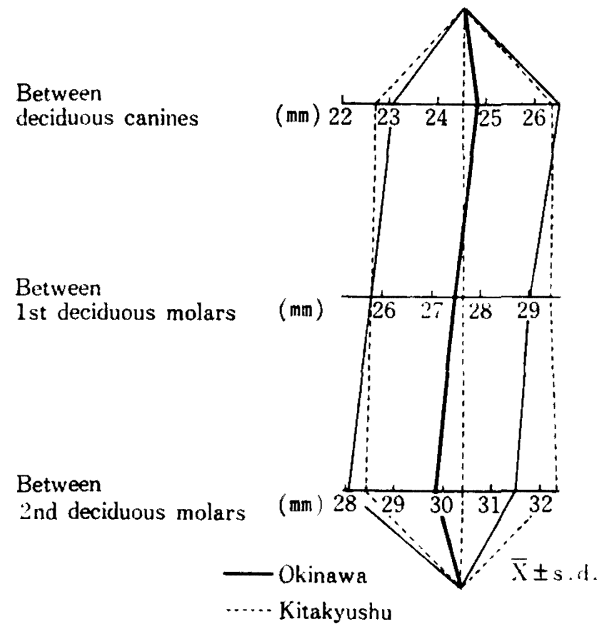

Fig. 6 Palatal breadths (boys)

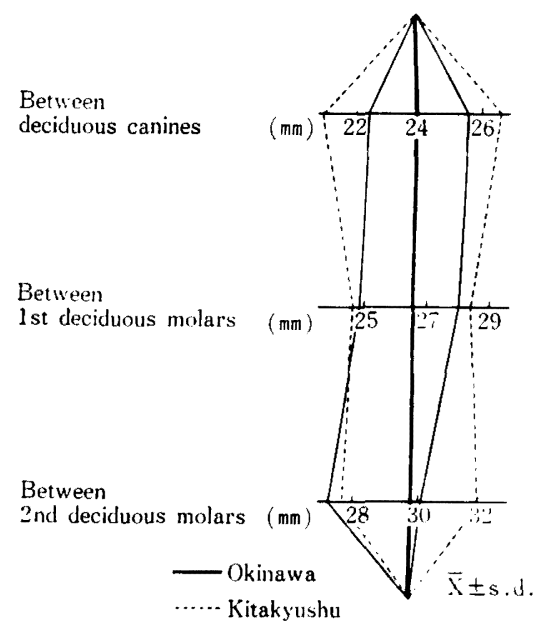

Fig. 7 Palatal breadths (girls)

girls. In contrast, in Okinawa children the length was greater, although not significantly, in girls. The length of the sutura palatina mediana of Okinawa boys was less than that measured in Kitakyushu boys by both Maeda ${ }^{12)}$ and $\mathrm{Ando}^{13)}$; the lengths were similar in Okinawa girls and Kitakyushu girls measured by Ando ${ }^{13)}$, but tended to be longer in Okinawa girls than in the girls measured by Maeda ${ }^{12}$ (Figs. 2, 3).

In Okinawa children, palatal arch lengths were greater, although not statistically greater, in boys than girls, which was the same tendency as noted in Kitakyushu children by Maeda ${ }^{12)}$ and $\mathrm{Ando}^{13}$. Maeda ${ }^{12)}$ found them greater for boys than for girls between the ages of 3 and 5 years, and he found the greatest

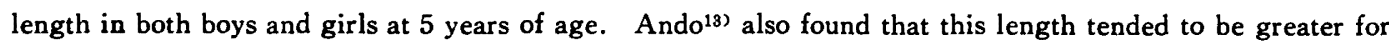
boys than for girls at any age. When the palatal arch lengths of Okinawa children are compared with those of Kitakyushu children they are shorter than those measured by Maeda ${ }^{12}$, except for the distance between deciduous canines in girls and between 1 st deciduous molars in both boys and girls. In comparison with the children measured by Ando ${ }^{13)}$, the distance between deciduous canines is longer in Okinawa children, but the distance between 2 nd deciduous molars in both boys and girls is longer in Kitakyushu children (Figs. 4, 5).

When assessing bilateral growth of the dental arch, measurements of palatal breadths are thought to be more exact than upper dental arch breadths because they are independent of the mesiodistal and buccolingual slopes. Ohzawa ${ }^{15)}$ noted that hereditary factors influenced this measurement, finding strong similarities among siblings and between twins. Lebret ${ }^{18)}$ reported that the alveolar process increased continuously in height and breadth.

Maeda ${ }^{12)}$ reported that palatal breadths, which are smaller than dental arch breadths, were greater for boys than for girls, and widest at the age of 5 years. According to Ando's), palatal breadths tend to be wider for boys than for girls at any site of measurement. In Okinawa boys, palatal breadths were greater between deciduous canines, between 1 st deciduous molars, and between 2 nd deciduous molars than they were for girls at all ages. This same tendency was found in Kitakyushu children by Maeda ${ }^{12}$ ) and Ando $^{132}$. When the palatal breadths of Okinawa children are compared with measurements taken by Maeda ${ }^{12)}$ and Ando ${ }^{13}$, the width between deciduous canines is greater in boys; the width between the 1 st deciduous molars is similar for boys and girls, and the distance between 2 nd deciduous molars is shorter in boys (Figs. 6, 7).

A summary of the above gives the following palatal trait features of Okinawa children : only palatal 
breadths show a significant difference between boys and girls; they are wider for boys. When compared with the Kitakyushu children measured by $\mathrm{Ando}^{13)}$, palatal heights of Okinawa children are less both in the anterior and posterior regions, and the length of the sutura palatina mediana is less, and although palatal arch lengths and palatal breadths are greater at the anterior region of palate, they tend to be smaller at the posterior. This finding agrees with that in unpublished data on dental arch morphology of Okinawa children; namely, there is a tendency for the posterior region of upper dental breadths to be similar in boys and girls, but for the anterior breadth to be greater in boys. Further, Kawano ${ }^{8}$, who reported the oral traits of adult women (permanent dentition) in Okinawa, found that they tended to have low values for posterior palatal heights and high values for the anterior-posterior palatal height index, the length of the sutura palatina mediana, and palatal breadths. The palatal traits of Okinawa children measured for this study did not have similar tendencies, suggesting that the oral traits in Okinawa Island natives with deciduous dentition are probably different from those with permanent dentition.

\section{References}

1) Krogman, S.: Anthropological aspects of the human teeth and dentition, J. Dent. Res., 7 ; 1, 1927.

2) Aoki, H., Tsuta, A. and Ukiya, M.: A morphological study and comparison of the dental arch form of Japanese and American adults : Detailed measurements of the transverse width, Bull. Tokyo dent. Coll., $12 ; 9$, 1971.

3) Kou, K.: Anthropological studies on the Mandarin Formosan mouth; 1. The size of the dental arch, SHIKWA GAKUHO, 72 ; 951, 1972.

4) Roun, B.: Anthropological studies on the Korean mouth; 1. The size of the dental arch, SHIKWA GAKUHO, $77 ; 905,1977$.

5) Saeki, E. : A conparative study on the dental arch and the palate among populations in Shimonoseki, Yawata and Beppu cities, J. Kyushu Dent. Soc, 12 ; 336, 1958.

6) Saeki, E.: Studies on the dental arch and palate in the female groups in Shimonoseki, Yawata and Beppu cities; III. Palatal breadth, alveolar breadth of lower jaw, and palatal arch length, J. Kyushu Dent. Soc., $17 ; 1,1963$.

7) Ninomiya, F., Suehara, Y., Yano, K. and Ueda, S.: A study on the dental arch and palate of a population in Kyushu, J. Kyushu Dent. Soc., $22 ; 119,1968$.
8) Kawano, M.: A study on the dental arch and the palate of Okinawa females, J. Kyushu Dent. Soc., 36 ; 940, 1982.

9) Nanakuma, I. : A study on the dental arch and the palate of Paiwan tribe (Taiwan aborigines), J. Kyushu Dent. Soc., 38; 712, 1984.

10) Nishioka, M.: A study on the dental arch and the palate of Rukai tribe (Taiwan aborigines), J. Kyushu Dent. Soc., 38 ; 1003, 1984.

11) Kitajima, R. : A study on the dental arch in human infants with reference to age, sex and regional difference, J. Kyushu Dent. Soc., 28 ; 190, 1974.

12) Maeda, Y.: A morphological investigation on the palate of infants, J. Kyushu Dent. Soc., $28 ; 1,1974$.

13) Ando, A.: A study on the dental diseases, and dental arch and palate of mentally retarded children, J. Kyushu Dent. Soc., 38 ; 26, 1984.

14) Ninomiya, F.: Heredity in the mouth; II. Hereditary traits in the mouth of twins, J. Kyushu Dent. Soc., 9 ; 1, 1955.

15) Ohzawa, Y.: A correlation study of the bucco-lingual crown breadth and the magnitude of palate in the pairs of brothers and sisters, IGAKU KENKYU, 30 ; 1909, 1960.

16) Lebret, L.: Growth changes of the palate, J. Dent. Res., 41 ; 1391, 1962. 